\title{
Evaluation of a model for induction of periodontal disease in $\operatorname{dog} s^{1}$
}

\author{
Rodrigo V. Sepúlveda ${ }^{2}$, Emily C.C. Reis ${ }^{2}$, Fabrício L. Valente², Daniel G. Brezinski ${ }^{2}$ \\ and Andréa P.B. Borges ${ }^{2 *}$
}

\begin{abstract}
Sepúlveda R.V., Reis E.C.C., Valente F.L., Brezinski D.G. \& Borges A.P.B. 2014. Evaluation of a model for induction of periodontal disease in dogs. Pesquisa Veterinária Brasileira 34(6):562-568. Departamento de Veterinária, Universidade Federal de Viçosa, Campus Viçosa, Avenida P.H. Rolfs s/n, Viçosa, MG 36570-000, Brazil. E-mail: andrea@ufv.br

There are several methods for inducing periodontal disease in animal models, being the bone defect one of the most reported. This study aimed to evaluate this model, through clinical, radiographic, tomographic and histological analyzes, thus providing standardized data for future regenerative works. Twelve dogs were subjected to the induction protocol. In a first surgical procedure, a mucoperiosteal flap was made on the buccal aspect of the right third and fourth premolars and a defect was produced exposing the furcation and mesial and distal roots, with dimensions: $5 \mathrm{~mm}$ coronoapical, $5 \mathrm{~mm}$ mesiodistal, and $3 \mathrm{~mm}$ buccolingual. Periodontal ligament and cementum were curetted and the defect was filled with molding polyester, which was removed after 21 days on new surgical procedure. Clinical and radiographic examinations were performed after the two surgeries and before the collection of parts for dental tomography and histological analysis. All animals showed grade II furcation exposure in both teeth. Clinical attachment level increased after induction. Defect size did not change for coronoapical and buccolingual measurements, while mesiodistal size was significantly higher than at the time of defect production. Radiographic analysis showed decreased radiopacity and discontinuity of lamina dura in every tooth in the furcation area. The horizontal progression of the disease was evident in micro-computed tomography and defect content in the histological analysis. Therefore, it is concluded that this method promotes the induction of periodontal disease in dogs in a standardized way, thus being a good model for future work.
\end{abstract}

INDEX TERMS: Periodontitis, surgical technique, dentistry, dogs.

RESUMO.- [Avaliação de um modelo para indução de doença periodontal em cães.] Existem vários métodos para indução de doença periodontal em modelos animais, sendo o do defeito ósseo um dos mais descritos. Este estudo objetiva avaliar esse modelo em cães, por análises clínica, radiográfica, tomográfica e histológica, fornecendo assim dados padronizados para trabalhos futuros. Doze cães foram submetidos ao protocolo de indução. Em um primeiro procedimento cirúrgico, um retalho mucoperiosteal foi pro-

\footnotetext{
${ }^{1}$ Received on November 8, 2013.

Accepted for publication on April 2, 2014.

${ }^{2}$ Departamento de Veterinária, Universidade Federal de Viçosa (UFV), Campus Viçosa, Avenida Peter Henry Rolfs s/n, Viçosa, MG 36570-000, Brazil. E-mails: rodrigo.sepulveda@ufv.br, emilycarlo@yahoo.com.br, fabriciovalente@gmail.com, danielbrezinski@yahoo.com.br; *Corresponding author: andrea@ufv.br
}

duzido na face vestibular do terceiro e do quarto dentes pré-molares direitos e foi criado um defeito, expondo a furca e parte das raízes mesial e distal, com as dimensões: $5 \mathrm{~mm}$ corono-apical, $5 \mathrm{~mm}$ mesio-distal e $3 \mathrm{~mm}$ vestíbulo-lingual. 0 ligamento periodontal e o cemento foram curetados e o defeito foi então preenchido com poliéster de moldagem, que foi removido após 21 dias em um novo procedimento cirúrgico. Exames clínicos e radiográficos foram realizados após as duas cirurgias e antes da coleta dos dentes e tecidos associados para análise tomográfica e histológica. Todos os animais apresentaram exposição de furca grau II em ambos os dentes. 0 nível clínico de inserção aumentou após a indução. 0 tamanho do defeito não apresentou alteração nas medidas corono-apical e vestíbulo-lingual, enquanto o tamanho mesio-distal foi significativamente maior que o produzido. Análise radiográfica mostrou diminuição da ra- 
diopacidade e descontinuidade da lamina dura na região da furca dos dois dentes. A progressão horizontal da doença foi evidente na microtomografia e pelo conteúdo do defeito nas análises histológicas. Assim, conclui-se que este modelo promove a indução de doença periodontal em cães de forma padronizada, sendo um bom modelo para trabalhos futuros.

TERMOS DE INDEXAÇÃO: Periodontite, técnica cirúrgica, odontologia, cães.

\section{INTRODUCTION}

Periodontal disease is the result of the immune-inflammatory response in periodontal tissues caused by the microflora of plaque accumulated on the tooth surface, with consequent loss of the supporting tissues of the tooth: gingiva, alveolar bone, periodontal ligament and cementum (Harvey 2005).

Loss of teeth is not the only consequence of periodontal disease, since the alveolar bone resorption can lead to pathologic fractures of the jaw and oronasal communication (Hale 2002, Legendre 2003, Carlo Reis et al. 2011b). This microflora is also responsible for frequent bacteremia which can lead to major systemic diseases, such as pneumonia, arthritis and infectious endocarditis (Harvey \& Emily 1993, Carlo Reis et al. 2011b).

Conventional treatment of periodontal defects includes the surgical access only to affected areas through a muco-gingival flap, curettage of plaque and calculus and polishing, followed by repositioning of the flap. In this case, cells from the junctional epithelium and fibroblasts of the gingival connective tissue proliferate rapidly, filling the defect area (Deliberador et al. 2006, Christgau et al. 2003). Thus, there is repair with connective tissue that does not have the support function that the periodontium needs, compromising oral health. The formation of cementum, periodontal ligament and alveolar bone does not occur or it is minimal, hence, this treatment can only prevent the progression of the disease and does not provide regeneration of the periodontium (Warrer \& Karring 1992, Cirelli et al. 1997, Carlo Reis et al. 2011b).

The use of biomaterials in the form of matrices or membranes have been studied in order to facilitate periodontal regeneration (Cirelli et al. 1997, Christgau et al. 2003, Shoukry et al. 2007, Reis et al. 2011, Carlo Reis et al. 2011a, Carlo Reis et al. 2011b) for use in both dogs and humans. In this context, studies have shown that periodontal disease in dogs is similar to that in human in various aspects such as etiology, pathophysiology, formation of periodontal pockets and tissue repair (Giannobile et al. 1994, Christgau et al. 2003, Oz \& Puleo, 2011). As a result, the dog is a candidate for such therapies as well as an excellent experimental model for the treatment of disease, including for being of a size compatible with surgical manipulation, unlike rats and mice (Giannobile et al. 1994, Oz \& Puleo 2011).There are several methods for inducing periodontal disease in several animal models, but each species responds best to a given method (Oz \& Puelo 2011).

The main methods for induction of periodontal disease are the method of ligation, where a suture (silk or cotton) is placed in the gingival sulcus of the premolars and molars favoring the accumulation of plaque (Oz \& Puelo 2011, Abe \& Hajishengallis 2013, Taut et al. 2013) and the method of bone defects where a bone defect is performed, and its spontaneous regeneration is prevented by occlusion of the defect with some material (Oz \& Puelo 2011, Carlo Reis et al. 2011a, Chantarawaratit et al. 2013).

In this sense, the present study aimed to evaluate an experimental model of periodontal disease in dogs with a chronic defect with a standard size and compatible with surgical techniques.

\section{MATERIALS AND METHODS}

This study was approved by the Ethics Committee of the Institution under protocol no 06/2009.

Twelve healthy adult female dogs, weighing between 10 and $15 \mathrm{~kg}$, from the Experimental Kennel of the Veterinary Department of the Institution were used. They had no periodontal disease, were vaccinated and treated against ecto and endoparasites. These animals were housed in individual stalls, receiving commercial feed and water ad libitum.

During the three days prior to surgery, each animal received prophylactic antibiotic therapy as the combination of spiramycin $(23.5 \mathrm{mg} / \mathrm{kg})$ and metronidazole $(12.5 \mathrm{mg} / \mathrm{kg})$ orally every 24 hours. Preoperatively immediately, dogs were sedated with acepromazine $(0.1 \mathrm{mg} / \mathrm{kg})$ intravenously (IV) as premedication, after fluid and solid deprivation of 12 hours. General anesthesia was induced with propofol $(6 \mathrm{mg} / \mathrm{kg}$, IV) and maintained with a mixture of isoflurane and oxygen.

Animals were placed in the left lateral position, exposing the buccal gingiva of the mandible that was cleaned along with the entire crown of the tooth with a solution of $0.12 \%$ chlorhexidine. A mucoperiosteal flap was performed after the incision of the gingival sulcus of the third and fourth premolars of the mandible on the rostrocaudal direction and then, vertical incisions were made on the gingiva caudal to the fourth premolar and rostral to the third premolar (Fig.1A). The flap was displaced apically exposing the alveolar bone. A defect was then induced by exposing the furcation and mesial and distal roots of the tooth with the aid of a tapered FG drill coupled to a high speed motor. The defect presented the following measures: $5 \mathrm{~mm}$ toward coronoapical (measured from the cemento-enamel junction to the most apical edge of the defect, measured at the center of the furcation), $5 \mathrm{~mm}$ mesiodistal, and $3 \mathrm{~mm}$ deep (buccolingual direction) measured from the surface of the alveolar bone to the lingual surface of the defect (Fig.1B). These measurements were performed using a periodontal probe with millimeter markings. The exposed roots were curetted using Gracey curette to remove the Sharpey fibers of the periodontal ligament and cementum. This morphology defect is classified as a grade II furcation defect (Cirelli et al. 1997, Christgau et al. 2003).

Then, the periodontal defect was filled with molding polyester (Fig.1C) to prevent spontaneous regeneration of acute defect and promote thereby a chronic contamination with bacteria in plaque (Christgau et al. 2003, Roriz et al. 2006). The flap was repositioned and sutured with simple interrupted pattern with 3-0 nylon (Fig.1D). At this time, radiographs of the operated area were obtained using dental intra-oral film and positioned by the technique of parallelism in the lingual region of each jaw.

Postoperatively, animals were given morphine $(2 \mathrm{mg} / \mathrm{kg})$ every six hours for 24 hours and after this period, meloxicam $(0.1 \mathrm{mg} / \mathrm{kg})$ orally for three days for analgesia. Throughout the postoperative period until the surgical wound healing animals received pasty diet. 


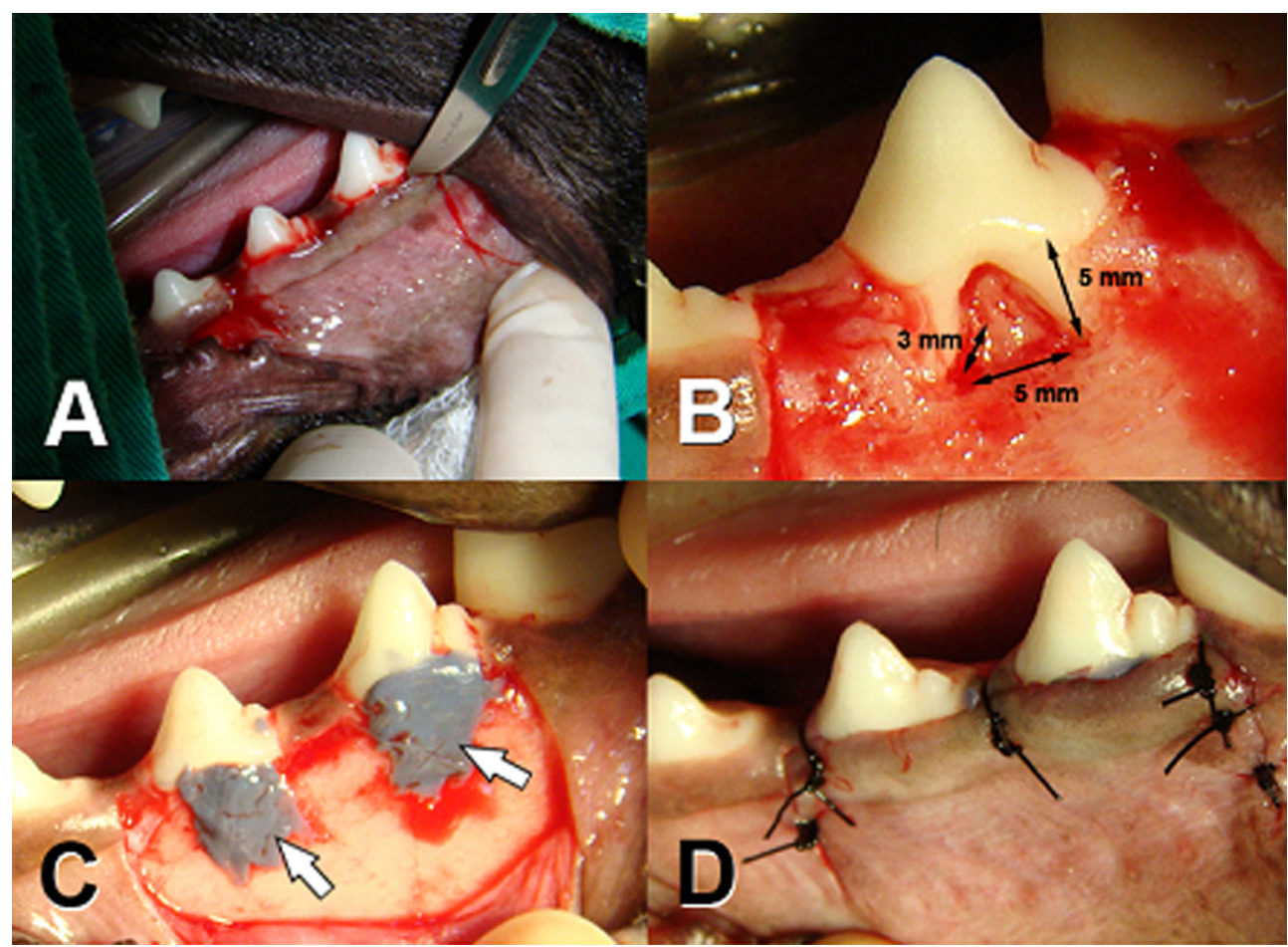

Fig.1. Surgical technique for the development of an experimental model of periodontal disease in dogs. (A) A mucoperiosteal flap was performed in the third and fourth premolars of the mandible by incising the gingival sulcus and the buccal gingiva. (B) A defect was created with a conical drill in high speed motor, exposing the furcation and the mesial and distal roots. (C) The defect was filled with molding polyester (white arrows) to prevent spontaneous regeneration. (D) The flap was then repositioned and sutured with simple interrupted pattern, in the mesial and distal region, using 3-0 nylon sutures.

Clinical examination consisted of daily observation of the surgical wound for two weeks after surgery, evaluating the presence or absence of bleeding, purulent discharge, dehiscence and exposure of the polyester.

After 21 days of induction of periodontal disease, polyester molding was removed and the attachment level was measured (from the cemento-enamel junction to the junctional epithelium or the bottom of the periodontal pocket or gingival sulcus). The defect was classified based on the furcation grade I, II or III and the experimental defects was measured. The animal received prophylactic treatment with periodontal scaling of existing plaque and calculus using curettes and ultrasonic dental followed by polishing. Also at 14 days post-professional periodontal treatment, each animal was anesthetized as described before and new radiographs of the area were obtained with the same technique previously described.

Then, a program of conventional treatment for periodontal disease was instituted, including the procedure for professional scaling and polishing followed by daily brushing and application of $0.12 \%$ chlorhexidine twice daily.

In the radiographic analysis, the radiopacity of the furcation area was compared with the alveolar bone at the base of it. The defect was rated according to the following scores: 0 - radiopacity of the defect smaller than the adjacent bone; (1) radiopacity similar to the adjacent bone; (2) defect radiopacity higher than the adjacent bone. The regularity of the edges of the defect was observed, each classified as regular or irregular edge. The presence or absence of the lamina dura and the periodontal ligament space were also observed.

Samples of the third premolar were harvested from six animals at 60 days postoperative with the aid of a circular diamond drill coupled to high speed motor. These samples were analyzed by micro-computed tomography (MicroCT) and scanned at $85 \mathrm{kV}$ and $77 \mathrm{~mA}$. Subsequently, the jaw was stabilized with the use of methylmethacrylate fixed to the rostral and caudal adjacent teeth. They were reconstructed, generating two-dimensional $10 \mathrm{~mm}$ thick sections, morphed together to form three-dimensional pieces from which images were obtained. These samples were used to establish parameters of trabecular thickness and number, as well as the separation between trabeculae. A sample of the an uninjured third premolar of an animal without periodontal disease and which died of natural causes at the Veterinary Hospital of the University was collected and analyzed as a reference.

Histological processing of samples from the other six animals was performed according to Carlo Reis et al. (2011a), including decalcification in formic acid solution and hematoxylin and eosin stain. Analysis included characterization of the tissue types in the furcation and presence of tissue regeneration.

Clinical and radiographic data were analyzed using paired t-test or Wilcoxon test for paired samples through SigmaPlot 11.0, accepting an error of $5 \%$. Tomographic and histological data were analyzed using qualitative analysis.

After the end of the experiment the animals were destined for adoption and were followed monthly until healing of the jaw followed by removal of methylmethacrylate with dental drills.

\section{RESULTS}

All animals showed mild hemorrhage during the first three postoperative days by touching the wound at the time of application of $0.12 \%$ chlorhexidine. None of the animals 
showed pus in the wound. Three animals had dehiscence of the suture: one on the second postoperative day, one on the third day and another on the ninth day. All animals presented the exposed polyester (Fig.2A), in at least one of two teeth, from the seventh postoperative day. At 21 days postoperatively, all animals showed grade II furcation exposure (Fig.2B) in both teeth, according to the classification of Hamp et al. (1975) still in use (Christgau et al. 2003, Deliberador et al. 2006, Carlo Reis et al. 2011a), associated with the formation of periodontal pockets (Fig.2C). In addition, bleeding on probing was common, occurring in almost all the buccal surfaces of the teeth probed under analysis. Radiographic analysis, after removal of the molding polyester, showed that of 24 observed teeth, $83 \%$ had a score of 0 for radiopacity and $27 \%$ score $1,41 \%$ had discontinued lamina dura (Fig.2D) and the other 59\% had absence of lamina dura. Paired t-test was used for all measurements except for third premolar coronoapical dimensions that failed in normality test, so Wilcoxon for paired samples was used. Clinical attachment level increased from $2.50 \pm 0.52$ to $6.33 \pm 2.10 \mathrm{~mm}$ in the third premolar and from $2.50 \pm 0.52$ to $7.08 \pm 3.06 \mathrm{~mm}$ in the fourth, with $\mathrm{p}<0.001$ for both teeth (Fig.3). The defect was created with a standardized size and did not change statistically in its coronoapical and buccolingual dimensions, but increased mesiodistally from the original $5 \mathrm{~mm}$ to $6.17 \pm 0.94 \mathrm{~mm}$ in the third premo- $\operatorname{lar}(\mathrm{p}=0.001)$ and to $6.67 \pm 1.61 \mathrm{~mm}$ in the fourth $(\mathrm{p}=0.004)$ (Fig.4). Micro-computed tomographic images showed that bone loss progressed beyond the mesial and distal edges of the defect originally created, even reaching the alveolar bone between adjacent teeth (Fig.5A,B). The values obtained show reduced alveolar bone in relation to a control sample (Table 1) and these data can serve as a reference for grade II furcation defects in future work. The defect produced in alveolar bone was filled with dense connective tissue, except for the area closest to the root, where the extracellular matrix was more spaced and disorganized (Fig.5C). Cementum and periodontal ligament could be observed only in small areas of the apical portion of the defect while in the coronal portion, junctional epithelium could be seen at the interface with the root.

\section{DISCUSSION}

The observed hemorrhage may be related to surgical trauma and also to rich vascularity of alveolar bone, since, according to Fófano et al. (2005), blood vessels are ruptured in surgical trauma. The absence of pus in the surgical wound may have been influence by the daily cleaning of the surgical area with a solution of $0.12 \%$ chlorhexidine and antibiotics during the postoperative period (Matsuura et al. 1995). The mechanical effect of feeding can be discarded as a cause dehiscence, since the animals received pasty

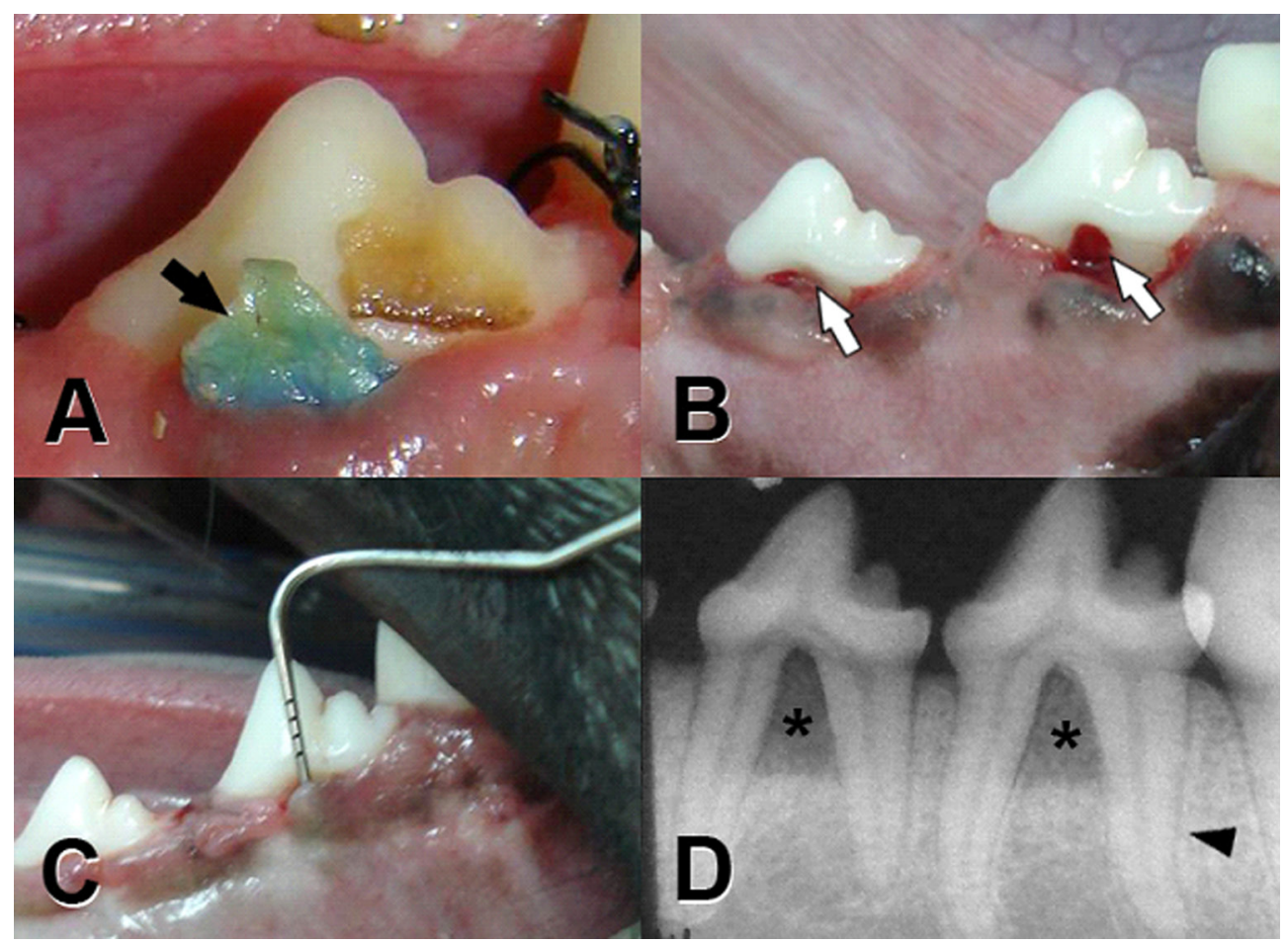

Fig.2. Clinical and radiographic results in the development of an experimental model of periodontal disease in dogs. (A) The molding polyester (black arrow) exposed to the oral cavity for induction of periodontal disease (stitches removal time). (B) Exposure of the grade II furcation (white arrows) seen 14 days after periodontal prophylaxis with spontaneous bleeding. (C) The pocket formation occurred in all defects, assessed by measuring probe with millimeter (immediately after periodontal prophylaxis). In this figure the probe marks a depth of $5 \mathrm{~mm}$. (D) Radiograph showing decreased radiopacity in furcation defects $\left(^{*}\right)$ and the discontinuity of the lamina dura (lamina dura presented in the region where periodontal disease was not induced - black arrowhead). 


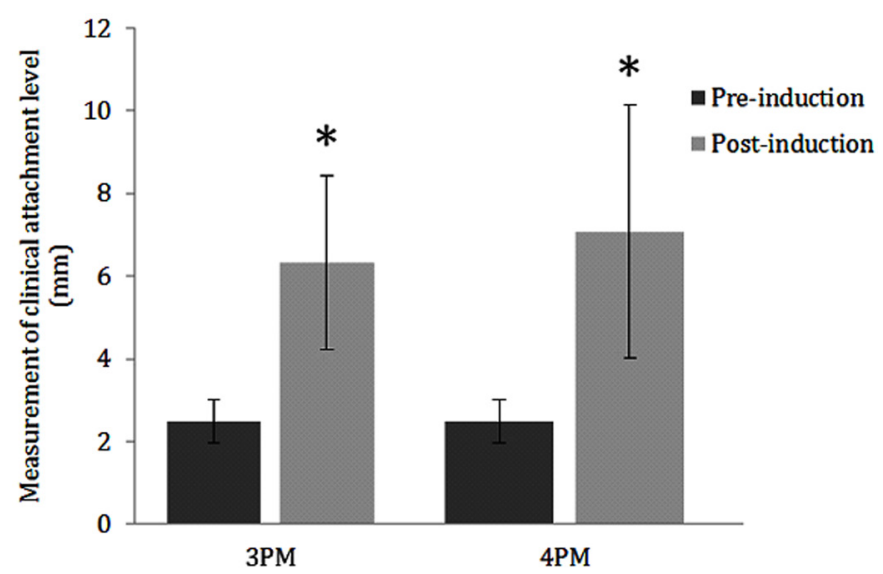

Fig.3. Mean and standard deviation of clinical attachment level measured in millimeters (mm) of the third (3PM) and fourth premolars (4PM) before and after the induction of periodontal disease at 21 days post-operative of twelve animals in the evaluation of a model for periodontal disease in dogs. *Represents statistical difference with $\mathrm{p}<0.05$.

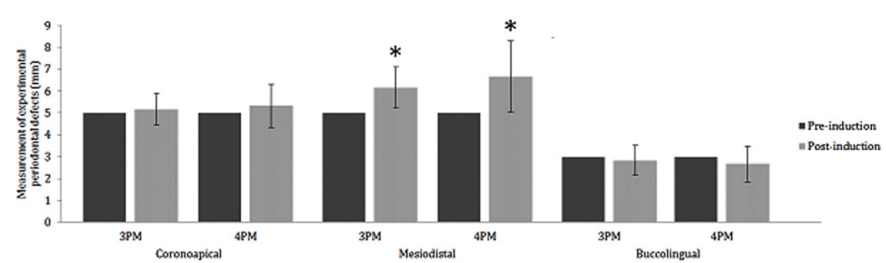

Fig.4. Mean and standard deviation of the measures in millimeters ( $\mathrm{mm}$ ) of coronoapical, mesiodistal and buccolingual experimental periodontal defects of the third (3PM) and fourth premolars (4PM) in dogs evaluated before and after induction of periodontal disease, the latter at 21 days postoperatively in the evaluation of a model for periodontal disease in dogs. *Represents statistical difference with $\mathrm{p}<0.05$.

diet after surgical procedures. Two factors may be involved in these observations. The first is the type of suture used simple pattern on the mesial and distal region, which can determine higher tension on site, predisposing to suture dehiscence. Similar data were reported by Duarte et al. (2007), which may suggest that the association of sutures in Sultan pattern, encompassing the central portion of the most coronal region of the flap to be more efficient procedure in that. Another factor that may be related to dehiscence is the infection of the defect - a process envisaged on the model and in accordance with the natural development of periodontal disease.

The permanence of molding polyester is desired to induce contamination and chronicity of the defect as occurs in periodontal disease. It is known that acute defects, obtained only with the completion of the defect and immediate coverage with mucoperiosteal flap regenerate spontaneously (Deliberador et al. 2006), what does not occur in periodontal disease (Christgau et al. 2003, Carlo Reis et al. 2011b). With the use of polyester, spontaneous regeneration is avoided and this material forms a direct and open communication of the defect with the oral cavity, leading to contamination and thus resulting in a defect very similar to that found in periodontal disease (Fig. 2B), agreeing with Macedo et al. (2006).
According Bernardo et al. (2007) and Gomes et al. (2007), furcation defects are directly related to tissue loss resulting from periodontal disease and therefore also increasing clinical attachment level that was significantly higher after disease induction $(\mathrm{p}<0.01)$. The bleeding on probing is a clinical parameter used to evaluate the presence of gingival inflammation and exudates in the periodontal pocket as it occurs in periodontal disease, and to monitor treatment. However, it is not the only parameter for information about the patient's periodontal condition (Karjaklainen \& Knuuttila 1996, Müller et al. 2000, Mallat 2007). According Offenbacher (2005), the complexity of etiologic factors of periodontal disease do not allow the use of only this parameter, being necessary others as the clinical attachment level and pocket depth, also used in this work.

Radiographic analysis showed that the technique was effective for inducing periodontal disease, that regeneration of the defect was not observed after 21 days of induction of periodontal disease and after 14 days of treatment with conventional scraping and polishing. These observations are similar to alveolar bone resorption that occurs naturally in disease and absence of the lamina dura, both radiographic signs of periodontal disease described by Gorrel (2010) who also cites the widening of the periodontal space as one of the radiographic signs of periodontal disease. The author also describes that the radiographic examination is essential to assess the extent of the destruction of the alveolar bone in patients with periodontal disease.

The measurement results of the defect before and after induction and the clinical attachment level corroborate regarding the establishment of periodontal disease with the proposed protocol, indicating no spontaneous regeneration of the defect. Therefore, the set up of a model of experimental chronic periodontal defect was accomplished. As for the mesiodistal measure, difference was observed before and after the induction of periodontal disease, demonstrating an increase. This supports the literature reports that the horizontal bone loss (mesialdistal) is greater than the vertical (coronoapical), as quoted by Tal (1984), Page et al. (1997) e Greenstein et al. (2009).

The horizontal progression of the disease was also evident in the three-dimensional reconstruction of tomographic images. These observations confirm the establishment of periodontal disease in the proposed model.Histologically, changes were also consistent with this type of injury. These observations are consistent with the evolution of periodontal disease occurring naturally and how it responds to treatment (Christgau et al. 2003, Carlo Reis et al. 2011a).

The results presented in this study demonstrate that it was possible to induce periodontal disease, obtaining a standardized class II furcation defect. Many biomaterials have been analyzed to promote periodontal regeneration of tissues lost by periodontal disease, but the majority of studies used acute defects (Robert \& Frank 1994, Kurtis et al. 2002) or non-standardized size defects (Christgau et al. 2003, Garcia et al. 2011). Thus, it is believed that the experimental model described in detail here will be useful for assessment in conditions similar to those of naturally occurring periodontal disease, but more objective and standardized. 


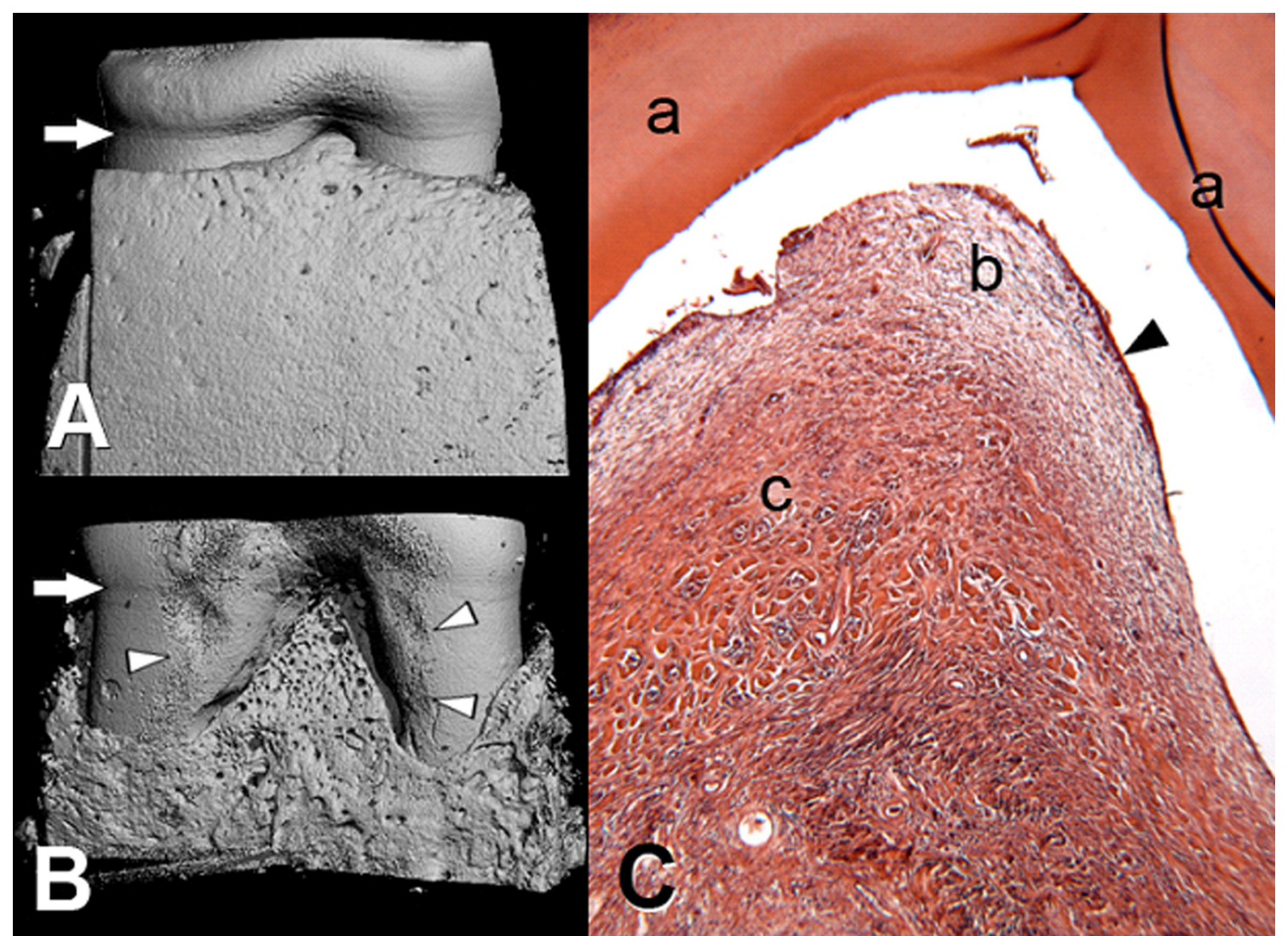

Fig.5. Reconstructed three-dimensional imaged $(A, B)$ and photomicrograph $(C)$ of the furcation of third $(A, B)$ and fourth premolars (C) for evaluation of an experimental induction model of periodontal disease in dogs. (A) Reconstructed three-dimensional image of the furcation of the third premolar of a dog without periodontal disease. Note the white arrow on the cementum-enamel junction. (B) Reconstructed three-dimensional image of the third premolar of a dog with induced periodontal disease showing a grade II furcation defect. Note the white arrow on the cementum-enamel junction and the white arrowheads delimiting the defect created experimentally. (C) Photomicrograph of the furcation of the fourth premolar of a dog with periodontal disease with grade II furcation. The black arrowhead indicates the junctional epithelium. Note that the space between the roots is filled with loose (b) and dense (c) connective tissue. The black arrowhead indicates the junctional epithelium. Roots are shown in (a).

Table 1. Mean and reference micro-computed tomographic data of the third premolar of dogs for evaluation of an experimental model for induction of periodontal disease in dogs

\begin{tabular}{lccc}
\hline & Reference & $\begin{array}{c}\text { Mean of animals } \\
\text { with induced disease }\end{array}$ \\
\hline Number of trabeculae (per $\left.\mathrm{mm}^{3}\right)$ & 3,82 & $0,97 \pm 0,75$ \\
Thickness of trabeculae (in mm) & 0,47 & $0,12 \pm 0,11$ \\
Separation between trabeculae (in mm) & 0,15 & $1,11 \pm 0,21$ \\
Density connection between trabeculae & 18,62 & $25,10 \pm 19,40$
\end{tabular}

\section{CONCLUSION}

Clinical parameters, radiographic findings, micro-computed tomographic data and histology confirmed the similarity of naturally-occurring periodontal disease in dogs with the experimental induced periodontal disease; furthermore, associated with the defect morphology maintained without spontaneous regeneration. Therefore, it can be concluded that it was possible to induce periodontal disease class II furcation defects in a standardized technique in dogs by a surgical technique associated with polyester, being this a good model for the induction of periodontal disease.
Acknowledgments.- The authors would like to thank CNPq, CAPES and FAPEMIG for financial support, and Dr. J.E. Davies of University of Toronto for MicroCT analysis.

\section{REFERENCES}

Abe T. \& Hajishengallis G. 2013. Optimization of the ligature-induced periodontitis model in mice. J. Immunol. Methods 394:49-54.

Bernardo C.C., Micheli G., Imbronito A.V., Carvalho V.F. \& Del Cioppo C.V. 2007. Avaliação do nível clínico de inserção de pacientes em manutenção periodontal. Revta Pós-Graduação, São Paulo, 13:345-352.

Carlo Reis E.C., Borges A.P.B., Araújo M.V., Mendes V.C., Guan L. \& Davies J.E. 2011a. Periodontal regeneration using a bilayered PLGA/calcium phosphate construct. Biomaterials 32:9244-9253.

Carlo Reis E.C., Borges A.P.B. \& Del Carlo R.J.D. 2011b. Regeneração periodontal em cães. Ciência Rural 41:2128-2136.

Chantarawaratit P., Sangvanich P., Banlunara W., Soontornvipart K. \& Thunyakitpisal P. 2013. Acemannan sponges stimulate alveolar bone, cementum and periodontal ligament regeneration in a class II furcation defect model. J. Periodontal Res. doi: 10.1111/jre.12090.

Christgau M., Aslanidis C., Felden A., Hiller K.A., Schmitz G. \& Schmalz G. 2003. Influence of interleukin-1 gene polymorphism on periodontal regeneration in intrabony defects. J. Periodontal Res. 33:20-27.

Cirelli J.A., MarcantonioJr E., Adriana R., Marcantonio C., Lia R.C., Goissis 
G. \& Rossa Jr C. 1997. Evaluation of anionic collagen membranes in the treatment of class II furcation lesions: an histometric analysis in dogs. Biomaterials 18:1227-1234.

Deliberador T.M., Nagata M.J.H., Furlanelo F.A.C., Melo L.G.N., Okamoto T., Sundefekd M.L.M.M. \& Fucini S.E. 2006. Autogenous bone graft with or without a calcium sulfate barrier in the treatment of class II furcation defects: a histologic and histometric study in dogs. J. Periodontol. 77:780-789.

Duarte T.S., Borges A.P.B., Lavor M.S.L., Filgueiras R., Tsiomis A.C., Fófano G., Odenthal M.E. \& Pontes K.C.S. 2007. Osseointegração da hidroxapatita sintética no processo alveolar da mandíbula de cães: aspectos clínicos e radiográficos. Arq. Bras. Med. Vet. Zootec. 59:114-118.

Fófano G., Borges A.P.B., Fonseca C.C., Vargas M.I., Carlo E.C., Viana V.W., Fontes E.B. \& Duarte T.S. 2005. Aspectos histológicos da associação da matriz óssea bovina mineralizada com membrana de colágeno na reparação alveolar da mandíbula de cão. Revta Ceres 52:955-965.

Garcia V.G., Fernandes L.A., Macarini V.C., Almeida J.M., Martins T.M., Bosco A.F., Nagata MJ., Cirelli J.A. \& Theodoro L.H. 2011. Treatment of experimental periodontal disease with antimicrobial photodynamic therapy in nicotine-modified rats. J. Clin. Periodontol. 38:1106-1114.

Giannobile W.V., Finkelman R.D. \& Lynch S.E. 1994. Comparison of canine and non-human primate animal models for periodontal regenerative therapy: results following a single administration of PDGF/IGF-I. J. Periodontol. 65:1169-1173.

Gomes S., Piccinin F., Susin C., Opperman R. \& Marcantonio R. 2007. Effects of supragingival plaque control on smoker and non-smoker: six month evaluation of pacients with periodontitis. J. Periodontol. 78:1515-1521.

Gorrel C. 2010. Small animal dentistry. $2^{\text {nd }}$ Ed. Elsevier, Philadelphia. 241p.

Greenstein B., Frantz B., Desai R., Proskin H., Campbell J. \& Caton J. 2009. Stability of treated angular and horizontal bony defects: a retrospective radiographic evaluation in a private periodontal practice. J. Periodontol. 80:228-233.

Hamp S.E., Nyman S. \& Lindhe J. 1975. Periodontal treatment of multirooth teeth. Results after 5 years. J. Clin. Periodontol. 2:126-135.

Hale F.A. 2002. Management of bilateral, pathologic, mandibular fractures in a dog. J. Vet. Dent. 19:22-24.

Harvey C.E. 2005. Management of periodontal disease: understating the options. Vet. Clin. North Am., Small Anim. Pract. 31:819-836.

Harvey C.E. \& Emily P.P. 1993. Small animal dentistry. Mosby, St Louis. 413p.

Karjaklainen K.M. \& Knuuttila M.L. 1996. The onset of diabetes and poor metabolic control increase gingival bleeding in children and adolescents with insulin-dependent diabetes mellitus. J. Clin. Periodontol. 23:10601067.

Kurtis B., Unsal B., Cetiner D., Gültekin E., Ozcan G., Celebi N. \& Ocak O.
2002. Effect of polylactide/glycolide (PLGA) membranes loaded with metronidazole on periodontal regeneration following guided tissue regeneration in dogs. J. Periodontol. 73:694-700.

Legendre L. 2003. Intraoral acrylic splints for maxillofacial fracture repair. J. Vet. Dent. 20:70-78.

Macedo G.O., Souza S.L., Novaes Jr A.B., Grisi M.F., Taba Jr M. \& Palioto D.B. 2006. Effect of early membrane removal on regeneration of class II furcation defects in dogs. J. Periodontol. 77:46-53.

Mallat M.A. 2007. Controlled 6-mounth clinical trial to study the effects of a stannous fluoride dentifrice on gingivitis. J. Clin. Periodontol. 34:762767.

Matsuura M., Herr Y. \& Han K. 1995. Immunohistochemical expression of extracellular matrix components of normal and healing periodontal tissues in the beagle dog. J. Periodontol. 66:579-593.

Müller H.P., Heinecke A. \& Eger T. 2000. Site specific association between supragingival plaque and bleeding upon probing in young adults. Clin. Oral Investig. 4:212-218.

Offenbacher S. 2005. Commentary: clinical implications of periodontal disease assessments using probing depth and bleeding on probing to measure the status of periodontal-biofilm interface. J. Int. Acad. Periodontol. 4:157-161.

Oz H.S. \& Puleo D.A. 2011. Animal models for periodontal disease. J. Biomed. Biotechnol. 2011:1-8.

Page R.C., Offenbacher S., Schroeder H.E., Seymour G.J. \& Kornman K.S. 1997. Advances in the pathogenesis of periodontitis: summary of developments, clinical implications and future directions. Periodontol. 2000. $14: 216-248$

Robert P.M. \& Frank R.M. 1994. Periodontal guided tissue regeneration with a new resorbable polylactic acid membrane. J. Periodontol. 65:414422.

Roriz V.M., Souza S.L., Taba jr M., Palioto D.B. \& Grisi M.F. 2006. Treatment of class III furcation defect with expanded polytetrafluoroethylene membrane associated or not with bone matrix/synthetic cell-binding peptide: a histological and histomorphometric study in dogs. J. Periodontol. 77:490-497.

Shoukry M., Ben Ali L., Abdel Naby M. \& Soliman A. 2007. Periodontal repair of experimental plaque-induced periodontal disease in dogs. J. Vet. Dent. 24:152-165.

Tal H. 1984. Relationship between the interproximal distance of roots and the prevalence of intrabony pockets. J. Periodontol. 55:604-607.

Taut A.D., Jin Q., Chung J.H., Galindo-Moreno P., Yi E.S., Sugai J.V., Ke H.Z., Liu M. \& Giannobile W.V. 2013. Sclerostin antibody stimulates bone regeneration following experimental peridontitis. J. Bone Miner. Res. DOI: 10.1002/jbmr.1984.

Warrer K. \& Karring T. 1992. Effect of Tisse ${ }^{\circledR}$ on healing afther periodontal flap surgery. J. Clin. Periodontol. 19:449-454. 